\title{
A MIRAGEM DA MISCIGENAÇÃo
}

\author{
FLÁVIO GOMES \\ ROQUINALDO FERREIRA
}

\section{RESUMO}

Neste artigo abordamos alguns aspectos da natureza da sociedade escravista - na África e no Brasil - especialmente os significados da liberdade, cor, protesto entre os séculos XVII a XIX. Partimos de um diálogo crítico sobre as perspectivas de miscigenação, políticas de domínio e dinâmicas sociais nas sociedades escravistas e os desdobramentos para o seu funcionamento e mudança.

\author{
PALAVRAS-CHAVE: escravidão; miscigenação; África; sociedade \\ escravista.
}

\section{ABSTRACT}

This article aims to focus some aspects concerning slave societies in Brazil and in Africa. In special, those related to the meanings of freedom, color, and protest between the eighteenth and nineteenth centuries. These issues are discussed from a critical dialogue on the perspectives about miscegenation, domination politics, social dynamics, and change in the slave societies.

KEYWORDS: slavery; miscegenation; Africa; slave societies.

[1] Stolcke, Verena. "Brasil: uma nação vista através da vidraça da raça". Revista de Cultura Brasileña, Madrid, $\mathrm{n}^{\mathrm{Q}}$ 1, mar. 1998. Essas imagens sobre a escravidão no Brasil remetem ao século XIX e foram produzidas em diálogos atlânticos com políticos, diplomatas, letrados, viajantes e abolicionistas. Ver: Azevedo, Célia Maria Marinho de. "Irmão ou inimigo: o escravo no imaginário abolicionista dos Estados Unidos e do Brasil". Revista USP, São Paulo, $\mathrm{n} ² 8$, 1995, pp. 96-109; e Abolicionismo. Estados Unidos e Brasil, uma história comparada (século XIX). São Paulo: AnnaBlume, 2003,pp. 35-58.
As temáticas em torno da miscigenação e da mestiçagem deram tons às perspectivas comparadas dos estudos sobre escravidão e relações raciais - especialmente Brasil e EUA — desde os anos 1940 com o projeto da Unesco e as expectativas intelectuais da época. Ontem e hoje, em razão de vários interesses, tem havido inúmeras reconstruções dessas (e outras) narrativas temáticas, por meio das quais se argumenta a respeito de um suposto passado visando a projetos de políticas públicas e esquemas sociológicos ${ }^{1}$. A sociedade lusobrasileira na maioria das vezes foi apresentada como a única com miscigenação — originada do paternalismo, clima e aptidões essenciais desconhecendo-se as lógicas para o Caribe e para outras áreas coloniais ibéricas. 
Mas o que o tema da miscigenação evoca? Muita coisa. E não se trata de enfatizar ou negar misturas. Sociais, políticas e culturais. E também étnicas. A questão é indagar o quanto essa temática - como fator estrutural - tem validade (num pressuposto de exclusividade) para se pensar sociedades do passado e aquelas do presente. Mais do que evidências, dados e mesmo argumentação histórica e sociológica, a miscigenação tem se tornado uma miragem, imagens que provocaram narrativas de viajantes, observadores estrangeiros, literatos e intelectuais desde o final do século XVIII; produziram classificações sociais, passando por ideologias que atravessariam o pós-colonial e inventariam a nação. No Brasil, o passado e o presente - escravidão e relações raciais - funcionariam como fios condutores de uma idéia migratória, justapondo argumentos e interesses, em diferentes contextos, escolhas e personagens, transformando miscigenação em algo naturalizado, real e ideal. Dizer que somos misturados ou houve miscigenação é tão óbvio como afirmar a nossa humanidade. Do que falamos e por que falamos? Ou de quem e com quem dialogamos, afinal? Do passado escravista? Da nação romantizada no alvorecer do século XX? Das narrativas que criaram a "nossa" identidade e cultura? Das políticas públicas do ontem e do hoje? Debates se colocam.

Neste ensaio propomos uma reflexão dialogando com um artigo recente de Rafael Marquese, "A dinâmica da escravidão no Brasil" 2 . Argumentamos em torno da experiência e do processo - ou das experiências e dos processos - da escravidão no (do) Brasil. A idéia não é insistir em polêmicas, eloqüentes e aparentemente bem intencionadas, de folhetins ou dar autoridade aos debates contemporâneos que margeiam abordagens sobre o passado histórico. Ainda que tornando explícitas as críticas, não propomos modelos para pensara "dinâmica" da sociedade escravista, embora reconheçamos a sedução que eles provocam. Sugerimos apenas contrapontos.

Deve ser bem recebido o artigo de Marquese sobre a "dinâmica da escravidão no Brasil". Com tratamento típico de uma renovada história atlântica, misturou teorias e reflexões. Parte do artigo (pelo menos as questões centrais) evocou debates - muitas vezes indiretos e silenciados - que mobilizaram intelectuais como Donald Pierson, Frank Tannenbaum, Octávio Ianni, Charles Boxer, Ciro Cardoso, Marvin Harris, Florestan Fernandes, Charles Wagley, entre outros. Surgem novos argumentos para uma idéia antiga: como entender a natureza das sociedades escravistas? Qual a razão da reprodução social interna tão duradoura em alguns casos? Quais os regimes sócio-raciais constituídos? Essas foram algumas das indagações que permearam várias abordagens comparadas entre Brasil e Estados Unidos, embora o Caribe e as sociedades escravistas como as da Colômbia e Venezuela tenham ficado estranhamente ausentes. Marquese, porém, escolheu
[2] Marquese, R. B. "A dinâmica da escravidão no Brasil. Resistência, tráfico negreiro e alforrias, séculos XVII aXIX".Novos Estudos, São Paulo, n² 74, 2006, pp. 107-123. 
caminhos próprios. Tentou explicar a não-reprodução de grandes quilombos (comunidades de escravos fugidos) coloniais - como Palmares - e o surgimento de "uma outra forma de resistência escrava coletiva", no caso as revoltas, levando em conta a "configuração que o escravismo brasileiro adquiriu a partir do final do século XVIII". Os eixos da sua argumentação são as "relações entre o tráfico negreiro transatlântico, alforrias e a criação de oportunidades para a resistência escrava coletiva (como a formação de quilombos e revoltas em larga escala), do final do século XVII à primeira metade do século XIX". Uma história escrita em grande escala, a partir da qual Marquese pretendeu ver mudanças na "configuração de um determinado tipo de sistema escravista". O que denominou "escravismo de plantation" no Brasil setecentista - ao contrário das áreas caribenhas, por exemplo - teria se transformado ao longo dos séculos XVIII eXIX. Com base em algumas "proposições teóricas", que consideravam "escravidão e a manumissão como partes de um mesmo processo institucional", sugeriu "um esquema interpretativo para o sentido sistêmico do escravismo brasileiro na longa duração, sem dissociar a condição escrava da condição liberta e o tráfico negreiro das alforrias".

\section{PALMARES E PALMARES: UM TEMA REVISITADO}

Acompanhando Marquese, estabelecemos, de início, um diálogo com o que denominou "enigma", ao indagar "por que não houve outros Palmares na história do Brasil?". Propomos — não antes ou depois, mas ao mesmo tempo - abordagens que possam indagar como e por que se constituíram os mocambos de Palmares e quais foram as narrativas sobre esses mocambos. Tal caminho nos coloca diante tanto da dimensão histórica como da análise historiográfica sobre "a dinâmica da escravidão" que se quis desenhar. São sugestivas abordagens que indicam "abalos na consciência colonial" nos textos dos letrados entre os séculos XVI e XVIII, destacando como a existência de comunidades de fugitivos e de revolta escrava endêmica foi também fator (não único ou determinante) para uma inflexão da ideologia escravista e das políticas de controle social. Isso não só a respeito da utilização generalizada do capitão-do-mato, mas também das expectativas com relação à mão-de-obra indígena e ao tráfico negreiro. As avaliações coevas de Antônio Vieira, negando qualquer possibilidade de acordos com os "palmaristas" ou a catequização deles, revelam expectativas senhoriais e coloniais. Também na história intelectual da historiografia de Palmares surgem outras indagações. Primeiro, por que Palmares foi excluído da historiografia póscolonial que inventou - ao formular identidades e biografias de uma dada Nação — a idéia de "nativismo"? Segundo, uma trilha oposta foi 
tomada pelas abordagens marxistas de Edison Carneiro, Clovis Moura e Décio Freitas - entre os anos de 1946 a 1982 -, que elegeriam Palmares como símbolo exclusivo de epopéia e heroísmo anticolonial. O que estaria sendo esquecido, silenciado ou enfatizado nas evocações sobre Palmares na literatura histórica do final do século XIX e ao longo do século XX? Por perspectivas diversas, esvaziou-seo evento de Palmares para o entendimento de uma determinada "dinâmica da escravidão" e suas relações com políticas coloniais do império português. Como numa avaliação desqualificadora, uma coisa seria Palmares, Zumbi, seu heroísmo e mitos étnicos dos movimentos sociais; e outra, a escravidão, ideologias e políticas de domínio. Esta pode ser uma equação complicada. O que Palmares nos ensina sobre as lógicas coloniais dos séculos XVI, XVII e XVIII? Entre silêncios e esquecimentos, como apareceu em fontes coevas? Visões românticas sobre durabilidade, heroísmo e mimetismos africanos pouco ajudam. ${ }^{3}$

Retomemos algumas considerações de um trabalho recente, quando revisitamos Palmares numa perspectiva atlântica. NaAmérica Portuguesa, há informações de mocambos desde o último quartel do século XVI. Na Bahia, desde 1575 já se registram fugas coletivas em todo o recôncavo. Os mocambos de Palmares não surgiram no século XVII, mas sim nos derradeiros anos do século XVI. Em abril de 1597, O provincial jesuíta Pero Rodrigues relatava ao padre João Álvares sobre questões da colonização e o problema da militarização. Dizia ter os "portugueses moradores nestas partes, três gêneros de inimigos por mar e por terra". Indicava: "os primeiros inimigos são os negros de Guiné levantados que estão em algumas serras, donde vêm a fazer [assaltos] e dar algum trabalho, e pode vir tempo em que se atrevam a cometer e destruir as fazendas, como fazem seus parentes na ilha de São Tomé". Em segundo, eram os "gentios por extremo bárbaros" e "os terceiros inimigos são os franceses". Além da ênfase, as referências destacam a dimensão atlântica do fenômeno das comunidades de escravos fugidos. No século XVI, um navio negreiro proveniente de Angola naufragou próximo da Ilha de São Tomé, e os sobreviventes africanos e seus remanescentes constituíram povoados denominados "angolares" e já consideráveis em 1572.4

É fundamental redimensionar o que representou Palmares para os holandeses durante a ocupação de Pernambuco. Sabemos que enviaram várias expedições para a repressão dos quilombos. E que também a economia açucareira não foi totalmente desorganizada - muitos fazendeiros permaneceram na região (alguns se refugiaram na Bahiae depois retornaram), enquanto outros ampliaram seus negócios nas plantações e engenhos abandonados - e que o tráfico negreiro continuou, em parte clandestino e com apoio de traficantes luso-africanos.
[3] Ver: Gomes, Flávio dos Santos. Palmares. Escravidão e liberdade no Atlântico Sul. São Paulo: Contexto, 2005; Guimarães, Carlos Magno. "Mineração, quilombos e Palmares. Minas Gerais no século XVIII". In: Reis, João José e Gomes, Flávio dos Santos. Liberdade por um fio. História dos quilombos no Brasil. São Paulo, Cia. das Letras, 1996, pp. 139-163; Lara, Silvia Hunold. "Do singular ao plural: Palmares, capitães-do-mato e o governo dos escravos" In: Ibidem, pp. 81-109; Silva, Rogério Forastieri da. Colônia e nativismo. A história como "biografia da nação". São Paulo: Hucitec, 1997; Vainfas, Ronaldo. "Deus contra Palmares. Representações e idéias jesuíticas". In: Reis, Gomes, op. cit., pp. 6o-80; e idem, Ideologia e escravidão. Os letrados e a sociedade escravista no Brasil Colonial. Petrópolis: Vozes, 1986

[4] Manuscrito publicado em Anais da Biblioteca Nacional, vol. 20, 1898 , p. 255. Ver também: Barros, Isabel Figueiredo de e Cruz, Maria Arlete. "Revoltas de escravos em São Tomé no século XVI". Leba, Lisboa, $\mathrm{n}^{\circ} 7$, 1992, pp.373-388. 
[5] Ver Nascimento, Rômulo Luiz Xavier do. Os "boschnegers" nas matas de Pernambuco e contra Nassau", 2004 (mimeo); idem, Pelo lucro da companhia: aspectos da administração no Brasil holandês (1630-1639). Recife: Dissertação de mestrado, Departamento de História, Universidade Federal de Pernambuco, 2004; Puntoni, Pedro. A mísera sorte. A escravidão africana no Brasil holandês e as guerras do tráfico no Atlântico Sul, 1621-1648. São Paulo: Hucitec, 1999.

[6] Gomes, Flávio dos Santos e Soares, Carlos Eugênio Líbano. "Sedições, haitianismo e conexões no Brasil: outras margens do atlântico negro". Novos Estudos, n 63, 2002, pp. 131-144.

[7] Genovese, Eugene.Da rebelião à revolução: as revoltas de escravos nas Américas. São Paulo: Global, 1983; Klein, Herbert S. A escravidão africana. América Latina e Caribe. São Paulo: Brasiliense, 1987; Price, Richard. "Resistance to slavery in the Americas: Maroons and their communities". Indian Historical Review, $\mathrm{n}^{\mathrm{Q}} 15$, vols. 1-2, 1988-1989); e idem, Sociedades cimarronas. Comunidades esclavas rebeldes en las Américas. Madrid: Siglo Ventiuno, 1981.
Não só isso, as narrativas sobre o crescimento de Palmares nas décadas da ocupação devem ser matizadas. Há evidências de fugas endêmicas e de pequenos grupos de quilombolas nas franjas dos engenhoss. Por variados motivos, uma certa memória histórica agigantou Palmares. Todos os escravos fugitivos rumavam para lá? A existência de mocambos mais populosos, suas conexões com a sociedade e o simbolismo que o envolvia atuavam como imagens de insurgência escrava generalizada, talvez amedrontando holandeses e portugueses. São indagações à espera de cotejo com as fontes e mais investigações, destacadamente holandesas. Na Jamaica, no século XVII, quilombos surgiram e cresceram - muitas vezes em oposição uns aos outros durante as lutas coloniais entre espanhóis e ingleses. Não foram raros os episódios, em torno deles, em período de guerras, invasões e disputas intercoloniais. Para a América Portuguesa temos exemplos de quilombos nas fronteiras da capitania do Grão-Pará com a Guiana Francesa na segunda metade do século XVIII, e o temor de migração, alianças, movimentação e circulação de "idéias revolucionárias". ${ }^{6}$

Imagens de vitórias e fracassos das lutas quilombolas têm explicações mais complexas, constituídas também por simbologias de "histórias nacionais" e reinvenções étnicas. Mesmo os tratados de paz impostos aos quilombolas da Jamaica e Suriname não foram incomuns. Aconteceram no México e Panamá, embora existam poucos estudos comparativos sobre as formas de negociação desses tratados junto aos agentes coloniais. Um dos primeiros teria ocorrido no México, em Vera Cruz, assinado em 1609, pelo líder Nyanga. Há indícios de tentativas de paz com fugitivos do Panamá, em 1570 e antes disso em Cartagena, em 1540, mas só efetivada em 1693. Na Martinica, em 1665, o líder quilombola Fabulé propunha paz, com tentativas de reconhecimento e liberdade7. Na América Portuguesa, capitania da Bahia,em 1640 - portanto bem antes dos tratados de paz com Ganga Zumba na década de 1670 - , autoridades da Câmara de Salvador chegaram a discutir a possibilidade de fazer um acordo com os mocambos baianos com o envio de um jesuíta que falasse a língua deles. Deveriam se render e serem engajados em tropas militares. Mas, por pressão de fazendeiros locais - temerosos de um mau exemplo para outros mocambos e a escravaria - esta possibilidade de tratado, ao que se sabe, não foi levada adiante.

Sobre os tratados de paz em Palmares e suas possibilidades, há semelhanças com os casos da Jamaica e Suriname em termos históricos, especialmente expectativas sobre a estrutura agrária, posto haver áreas valorizadas e relações com a autonomia de entrepostos circunvizinhos. Palmares também estava conectado com vários setores da sociedade pernambucana. De um lado, a sua extinção era fundamental - real e simbolicamente - para a elite local que se revezou no 
poder da capitania na segunda metade do séculoXVII. Exterminá-lo se confundia com o reconhecimento da lealdade lusitana e denodo colonial de alguns governadores e homens da política que tinham atuado em outros postos do império português. Por isso havia pressões junto ao Conselho Ultramarino. Não poucos senhores reclamaram da continuada extorsão de recursos solicitados nas expedições antimocambos. Vários outros setores - pequenos lavradores e vilas de indígenas aldeados - podiam estar articulados a Palmares, localizados em áreas de fronteiras econômicas em expansão. Havia ainda o interesse dos paulistas por terra - como sugere Alencastro - para expandir a agricultura e atrair mão-de-obra indígena apresada. Não é por acaso que parte substantiva da documentação sobre Palmares é dos anos 1670 a 1690 e enviada ao Conselho Ultramarino, tratando de negociações dos paulistas. $^{8}$

Nos tratados de Palmares falava-se que os palmaristas poderiam continuar mantendo trocas mercantis com comerciantes, vendeiros e lavradores da região; as terras que os palmaristas iriam viver seriam agora demarcadas pela Coroa; os cativos que continuassem fugindo para Palmares deveriam ser imediatamente devolvidos para as autoridades coloniais e seus respectivos proprietários; e passariam à condição de vassalos do rei. Nada muito diferente - guardadas as especificidades - do que aconteceu na Jamaica. Como entender tal processo como "derrota" sem refletir a respeito das dimensões desses tratados, por exemplo, para as respectivas sociedades coloniais? E não dá para falar de "vitórias" como sugere Marquese ao comparar com Palmares. $\mathrm{Na}$ Jamaica, quilombolas assinaram um tratado, em 1738, com os ingleses após décadas de batalhas nas florestas. Foram então reconhecidos a liberdade, a autonomia, a posse da terra e o direito de caçar e cultivar9. Os tratados de paz da Jamaica e Suriname - principalmente os de Palmares - também devem ser analisados do ponto de vista das lógicas euro-africanas. Políticas coloniais andavam às voltas com tráfico, alianças, conflitos, embaixadas, acordos, tratados e guerras com sociedades africanas do Ndongo, Matamba, Cassange, além do Reino do Congo desde o século XV. Há ainda muito que se analisar sobre as dimensões dos tratados de Ganga-Zumba, em 1678, e ainda mais sobre a onda de repressão entre 1691 e 1697 , especialmente sobrea participação dos paulistas, disputas entre câmaras locais e autoridades coloniais. Havia valorização das terras onde estava Palmares, destacadamente áreas de fronteiras econômicas abertas. Muitas sesmarias foram doadas nos anos 1670 e 1680. Mesmo antes, em 1660, retornando de um exílio consentido - quando da ocupação holandesa -, "moradores e povoadores da capitania da Bahia" solicitavam cartas de sesmarias para "povoar as terras devolutas, e sertão desta Capitania de Pernambuco chegados e vizinhos dos rebeldes dos mocambos e Pal-
[8] Alencastro, Luiz Felipe. O trato dos viventes. Formação do Brasil no Atlântico Sul, séculos XVI e XVII. São Paulo: Cia. das Letras, 200o; e Metcalf, Alida. "Millenarian slaves? The santidade de Jaguaripe and slave resistance in the Americas.American Historical Review, dez.1999, pp.1531-1559.

[9] Campbell, Mavis C. "Marronage in Jamaica. It's origen in the seventeenth century". In: Rubin, Vera e Tuden, Arthur. (orgs.) Comparative perspectives on slavery in new world plantation societies. Volume 292, Nova York, 1977, pp. 389-419; Grott, Silvia W. de. "A comparison between the history of Maroon communities in Surinam and Jamaica". Slavery $\mathcal{E} A$ bolition, vol. 6, n² 3, dez. 1985, pp. 173184; e Sheridan, Richard B. "The Maroon of Jamaica, 1730-183: livelihood, demography and health". Slavery $\mathcal{E}$ Abolition, vol. $6, \mathrm{n}^{2} 3$, dez. 1985 . 
[10] Ver Guimarães, Carlos Magno. "O quilombo do Ambrósio: lenda, documentos e arqueologia". Estudos Ibero-Americanos, Porto Alegre,vol.16, $\mathrm{n}^{\mathrm{Q}}$ 1-2, 1990, pp. 161-174; Uma negação da ordem escravista. Quilombos em Minas Gerais no século XVIII. São Paulo: Ícone, 1988; Ramos, Donald. "O quilombo e o sistema escravista em Minas Gerais do século XVIII". In: Reis, Gomes, op. cit.,pp.164-192; Scarano, Julita. Cotidiano e solidariedade. Vida diária da gente de cor nas Minas Gerais, século XVIII. São Paulo: Brasiliense, 1994; e Vallejos, Júlio Pinto. "Slave control and slave resistance in colonial Minas Gerais, 1700-1750". Journal of Latin American Studies, vol. 17, parte I, mai. 1985, pp. 23-25. mares". Foram várias as terras demarcadas como áreas "confinando com o mocambo e Palmares dos negros fugidos com todas suas ribeiras, lagoas e matos". A ocupação da região sob controle colonial estava contida pela existência de Palmares. Não poucos sesmeiros desistiram inicialmente de montar seus negócios; e posteriormente, em 1694, passaram a reivindicar doações anteriores. A expansão da fronteira agrária estaria agora garantida com as informações a respeito da erradicação dos palmaristas e o estabelecimento de aldeamentos indígenas realizados pela Coroa.Além disso, Palmares - como formação de inúmeros quilombos - não é "derrotado" em 1695 com o assassinato de Zumbi e o grande ataque à serra da Barriga. Há evidências de movimentação de quilombolas até 1742 na capitania de Pernambuco, aquartelamento de vilas de índios aldeados na região, lideranças palmaristas de Mouza e Camoanga, e migração dos remanescentes para as capitanias da Paraíba e Bahia, fugindo da repressão e da fronteira indígena das áreas do Rio Grande do Norte.

Sobre Minas Gerais no século XVIII, mais do que procurar grandes mocambos e projetos abortados de outros Palmares, temos que refletir sobre os significados coloniais da endemia das comunidades de fugitivos. Primeiro, conhecer a localização de quilombos tanto próximos às zonas de produção aurífera como em fronteiras e "sertões" abertos. Temos ali um grande fluxo de tráfico negreiro, áreas de enriquecimento e empobrecimento meteóricos e tensões sociais explosivas. Os argumentos citados de Ramos e Vallejos sobre quilombos como "válvula de escape" não consideram a disposição sociodemográfica da escravidão em Minas Gerais e a simbiótica - e profundamente subversiva - proximidade dos quilombolas com os setores envolventes. Não amortecia as tensões, mas tornavam as mesmas endêmicas e constantemente reconfiguradas. Temores de revoltas escravas, também de setores livres, coexistiram com contrabando, corrupção fiscal generalizada e mudanças nas políticas de domínio metropolitano. Paupérrima, a população crescente de libertos dominava os cenários, sob forte controle e repressão, de lavras esgotadas, das roças de alimentos, das áreas urbanas em caos e do banditismo social. Nas Minas Gerais, autoridades coloniais olharam sempre os libertos e a população negra e mestiça livre como solidários aos quilombolas e dos planos de revoltas. Para explicar a mudança na perspectiva do protesto escravo coletivo dos quilombos - no caso daqueles mais populosos -, no século XVIII, não dá apenas para recorrer às explicações em torno da "institucionalização da figura do capitão-do-mato e a definição de quilombo como qualquer ajuntamento composto por alguns poucos escravos fugitivos". ${ }^{10}$

Comunidades quilombolas - seguindo lógicas próprias estavam ao mesmo tempo fragmentadas, articuladas e avançando 
fronteiras, muitas das quais protegidas por barreiras de ocupação indígena. O sucesso contra Palmares também pode ser explicado pela mudança de estratégia na formação de alguns quilombos coloniais. Quando da onda de destruição em 1689-1694, há notícias de migração de vários grupos de quilombolas para as franjas das capitanias da Paraíba e Bahia. Mesmo em Pernambuco, na década de 1830, os camponeses negros papa-méis da Cabanada estavam estacionados nas serras onde habitaram os palmaristas coloniais. Em que medida a dispersão em pequenos grupos não fez parte de estratégias empregadas pelos quilombolas a partir do século XVIII? Para Minas Gerais, endemia, migração permanente, fronteiras abertas e alianças com grupos indígenas devem ser redimensionadas. As expectativas de que os quilombos mineiros deveriam crescer até Palmares ou ter ganhado aspectos semelhantes de oposição anticolonial estão mais na cabeça dos historiadores do que estiveram para quilombolas e setores envolventes da economia mineira. Mais úteis seriam as comparações entre os quilombolas de Minas Gerais e os das áreas mineradoras da Colômbia, por exemplo."

\section{SOCIEDADES AFRICANAS, TRÁFICOS E ESCRAVIDÕES}

Também precisamos saber mais sobre a história da África e seus intelectuais. E, no Brasil, isso é um desafio acadêmico atual que deve dispensar apenas boa vontade em reproduzir generalizações de manuais ou improvisos, ainda que bem intencionados. Marquese se vale de uma proposição de Igor Kopytoff, antropólogo com pesquisa de campo na Nigéria, que afirmou: "a escravidão não deve ser definida como um status, mas sim como um processo de transformação de status que pode prolongar-se uma vida inteira e inclusive estender-se para as gerações seguintes". Tal argumento se insere numa discussão africanista sobre o caráter da escravidão na África, não no Brasil. Resumidamente, essa historiografia se divide em dois eixos, remanescentes de debates da década de 1960, que opunham Walter Rodney a J. $\mathrm{Fage}^{12}$. O primeiro enfatizou o caráter transformador das forças externas representadas pelo comércio europeu a partir do século XV. Seria o comércio externo - tráfico atlântico - que teria transformado a escravidão africana numa instituição de tipo comercial. O corolário foi uma situação de guerra perene, estimulada pela absorção de produtos trazidos do Atlântico, e sem reprodução biológica de populações escravizadas. Apesar de variações e nuanças, as principais proposições de Rodney acabaram refletidas nos diferentes estudos de Claude Meillassoux, Paul Lovejoy e Ralph Austen ${ }^{13}$. De outro lado, surgiam historiadores que viam a escravidão como uma instituição que precedeu os contatos com europeus, sendo intrínseca à vida social na África. Nesta
[11] Karasch, Mary. "Os quilombos do ouro na capitania de Goiás”. In: Reis, Gomes, op. cit., pp. 240-262. Sobre Colômbia, ver McFarlane, Anthony. "Cimarrones and palenques: runaways and resistance in colonial Columbia". Slavery $\&$ Abolition, vol. 6, n² 3, dez.1985, pp.146-147.

[12] Fage,J. D. "Slavery and the slave trade in the context of West African history". Journal of African History, vol. 10, n 3, 1969; idem, "Slaves and society in Western Africa, c. 14451700 ". Journal of African History, vol. 21, nº 3, 1980; Rodney, Walter, "African slavery and other forms of oppression on the Upper Guinea Coast in the context of the atlantic slave trade". Journal of African History, vol. $7, \mathrm{n}^{\mathrm{9}} 3,1996$.

[13] Meillassoux, Claude, The anthropology of slavery: The womb of iron and gold. Chicago: The University of Chicago Press, 1991; Lovejoy, Paul, Transformations in slavery. Cambridge: Cambridge University Press, 1983; Austen, Ralph, African economic history: internal development and external dependency. Londres, 1987. 
[14] Para um balanço do debate, ver: Manning, Patrick. Slavery and African life: Occidental, Oriental, and African slave trades. Cambridge: Cambridge University Press, 1990; Miller, Joseph. "The world according to Meillassoux: a challenging but limited vision". International Journal of African Historical Studies, vol. 22, $\mathrm{n}^{\mathrm{Q}} 3$, 1989; Lovejoy, Paul, “Miller's vision of Meillassoux". International Journal of African Historical Studies, vol. 24, $\mathrm{n}^{\mathrm{a}}$ 1, 1991. No Brasil, parte desse debate foi publicado em Manning, Patrick. "Escravidão e mudança social na África". NovosEstudos, n² 21, jul.1988, pp. 8-29.

[15] Miers, Suzanne, e Kopytoff, Igor. "African slavery as an institution of marginality". In: Slavery in Africa: historical and anthropological perspectives. Madison: University of Wisconsin Press, 1977.

[16] Klein, Martin, "The study of slavery in Africa". Journal of African History, vol.19, n⿳⺈ 4, 1978; Cooper, Frederick, "The problem of slavery in African studies". Journal of African History, vol. 20, $\mathrm{n}^{\mathrm{Q}} 1,1979$

[17] Para exceções, ver vários trabalhos de Lovejoy sobre revoltas escravas: Lovejoy, Paul. "Concubinage and the status of women slaves in early colonial northern Nigeria". Journal of African History, vol. 29, $\mathrm{n}^{\mathrm{Q}}$ 2, 1988; Ver também Glassman, Jonathon. "The bondsman's new clothes: the contradictory consciousness of slave resistance on the Swahili coast".Journal of African History, vol. 32, n² 2,1991. perspectiva, a escravidão seria caracterizada como etapa transitória no processo de incorporação de indivíduos - necessariamente estrangeiros - desprovidos de laços de parentesco numa determinada comunidade ${ }^{14}$. Situada na segunda tradição referida acima, a análise de Kopytoff encontra-se, portanto, mais preocupada com a incorporação de escravos dentro de comunidades africanas do que com o fenômeno da manumissão em si ${ }^{15}$. Para Kopytoff, a associação entre escravidão e propriedade - comum nos regimes escravistas das Américas - não se aplica à Áfica. Nesta, escravos não eram propriedades, mas sim ocupavam uma condição liminar fadada a desaparecer. Ademais, a relação entre escravidão e estruturas de parentesco africanas não era de oposição. Menos uma instituição econômica do que um mecanismo para arregimentar clientes, a escravidão podia ter efeitos decisivos no âmbito político. Na condição de "estrangeiros", cativos serviam como instrumentos das disputas locais, alterando estruturas de poder tradicionais. Aspectos como conflitos sociais entre senhores e escravos, assim como a relação entre mercado e transformações da escravidão, estão ausentes da análise ${ }^{16}$. De qualquer forma, as duas tradições historiográficas sucumbiram na tentativa de generalizar para toda a África modelos pautados em exemplos derivados de situações locais. Além disso, se comparados com estudos sobre escravidão nas Américas, torna-se evidente que a historiografia sobre escravidão no continente africano tem sido vítima de dois problemas. Primeiro, a falta de fontes escritas, que são relativamente abundantes para regiões sob influência portuguesa, como Congo e, principalmente, Angola, mas dramaticamente escassas para outras regiões africanas. $O$ quadro em relação às fontes reflete a interação costeira dos europeus com os africanos e só muda quando se iniciam as viagens de exploração científica, na segunda metade do século XIX. O segundo problema deriva da talvez excessiva preocupação dos especialistas com causas e contornos institucionais do cativeiro, em detrimento de temas mais "visitados" pela historiografia sobre escravidão nas Américas, tais como cotidiano, família e comunidades. ${ }^{17}$

Essas considerações sobre os estudos africanistas reforçam argumentos ao nosso desacordo com Marquese no tratamento da história africana e na avaliação que faz sobre o papel do tráfico na "nova configuração do escravismo", como variável quase a-histórica, exógena em termos demográficos e econômicos. Freqüentemente nos estudos sobre a escravidão no Brasil, as sociedades africanas, suas dimensões e significados do comércio (não só de mão-de-obra) e tráfico atlântico têm sido vistos, muitas vezes, como variáveis passivas. As dimensões atlânticas sul-sul — não necessariamente só uma história dos Impérios - no âmbito de uma história social e política, são raras nas reflexões disponíveis. Vejamos algumas implicações. Nos 350 anos de trá- 
fico atlântico, 40\% dos cativos enviados para as Américas foram embarcados do Congo e Angola. O Brasil, por outro lado, se constituiu no principal destino do tráfico, recebendo em torno de $40 \%$ dos africanos enviados para as Américas. Ilustrando a intensidade dos laços angolanos com o Brasil, cerca de dois terços dos africanos trazidos para cá foram embarcados nos portos do Congo e de Angola. Palmares foi criado na primeira metade do século XVII, quando os portugueses - sozinhos - foram responsáveis por aproximadamente 70\% dos escravos trazidos para as Américas. Mais importante: $85 \%$ dos africanos embarcados naquela altura saíram de portos da África Central. ${ }^{18}$

Na primeira metade do século XVII, o tráfico angolano era principalmente feito a partir de Luanda, onde os suprimentos de cativos resultavam de operações militares de forças "portuguesas" e seus aliados Imbangalas contra os reinos Mbundu do Ndongo e Matamba. Constitui-se no único período em que houve uma correlação direta entre militarismo e embarques de escravos em Luanda ${ }^{19}$. Não surpreende, portanto, que, apesar de também populações indígenas, Palmares tenha sido associado aos povos Mbundu. Mas não seria de todo impossível a presença de africanos da Alta Guiné, bem como de outras regiões, sendo traficados. Segundo Alencastro, em 1639, a Companhia das Índias Ocidentais enviou para Pernambuco 2.400 africanos provenientes do Daomé, Benin, delta do Níger, Calabar e Camarões ${ }^{20}$. Com a endemia das fugas e mocambos, muitos desses africanos podem ter parado em Palmares.

Os povos Mbundu, na verdade, não foram os únicos afetados pelo tráfico na África Central. Embora seja inegável que a maioria dos cativos embarcados por Luanda fosse Mbundu, povos Kikongo e africanos oriundos do planalto central angolano foram também embarcados naquela cidade. Isso se torna patente através da análise das transformações do tráfico e das ligações comerciais entre Luanda e outras regiões da África Central. No século XVI, o tráfico se concentrou no norte da África Central, na costa do Loango e do Congo ${ }^{21}$. No início, os embarques de cativos foram relativamente centralizados, mas não demorou muito para que os interesses de negociantes locais baseados em São Tomé e Congo prevalecessem - em detrimento de grupos mercantis metropolitanos e do próprio Estado português. ${ }^{22}$ Em parte como resposta à erosão dos interesses metropolitanos na costa do Congo, a cidade de Luanda foi fundada em 1576.A fundação de uma cidade "européia" em plena África Central criou um precedente absolutamente singular, já que, pela primeira vez, europeus exerciam controle total sobre o comércio costeiro de escravos ${ }^{23}$. Luanda acabaria se tornando o porto mais importante do tráfico atlântico, onde mais de 2 milhões de pessoas foram embarcadas para as Américas - principalmente para o Brasil — entre os séculos XVIe
[18] Eltis, David. "The volume and structure of the transatlantic slave trade: a reassessment". William $\mathcal{E}$ Mary Quarterly, vol. LVIII, n. 1, 2001, pp. 17-42; "The transatlantic slave trade: a reassessment based on the second edition of the transatlantic slave trade dataset" (mimeo).

[19] Thornton, John. Africa and africans in the making of the atlantic world, 1400-1800. Cambridge: Cambridge University Press, 1999; idem, "Warfare, slave trading and European influence: Atlantic Africa, 1450180o". In: Black, Jeremy (ed.). War in the early modern world. London: UCL Press, 1999; idem, Warfare in Atlantic history. London: UCL Press, 2000.

[20] Ver inicialmente Kent, R. K. "Palmares: An African State in Brazil". Journal of African History, vol. 6 $\mathrm{n}^{\mathrm{Q}} 2$, 1965; Allen, Scott Joseph.Africanisms, mosaics, and creativity: the historical archaelogy of Palmares. M. A. Thesis: Brown University, 1995; Bastide, Roger. "The other quilombos". In: Price, Richard (org.). Maroon societies: rebel slave communities in the Americas. 2a.ed. Baltimore: The Johns Hopkins University Press, 1979, pp. 191-201; Schwartz, Stuart B. "Mocambos, quilombos e palmares: a resistência escrava no Brasil colonial". Estudos Econômicos. São Paulo: IPE-USP, v. 17, número especial, 1987 , pp. 61-88; Alencastro, op. cit.; Anderson, Robert N. "The Quilombo of Palmares: a new overview of a maroon state in seventeenth-century Brazil". Journal of Latin American Studies, vol. 28, 1996, pp. 553-562; Karasch, Mary. "Zumbi of Palmares: challenging the portuguese colonial order". In: Andrien, Kenneth J.(ed.).The human tradition in Colonial Latin America, Human tradition around the world. Wilmington: SR Books/Scholarly Resources, 2002.

[21] Os primeiros embarques do Congo foram analisados por Hilton e Thornton, mas o tratamento mais recente, e preciso, está em Elbl, Ivana. "The volume of the early atlantic slave trade". Journal of African History, vol. $38, \mathrm{n}^{\mathrm{Q}} 1,1997$, p. 43 .

[22] Thornton, Africa and Africans in the making of the atlantic world, $1400-$ 1800 , op. cit., pp. 61-62; Klein, Herbert. "The atlantic slave trade to 1650". In: Schwartz, Stuart B. Tropical Babylons: sugar and the making of the atlantic world, 1450-1680. Chapel 
Hill: University of North Carolina Press, 2004, pp. 211-212.

[23] Miller, Joseph. "The slave trade in Congo and Angola". In: Kilson, Martin e Rothberg, Robert I. (eds.). The African diaspora: interpretative essays. Cambridge: Harvard University Press, 1976; idem, "The paradoxes of impoverishment in the atlantic zone". In: Birmingham, David e Martin, Phyllis (eds.). History of Central Africa. London: Longman, 1983; idem, "Central Africa during the era of the slave trade, c.1490s-1850s".In: Heywood, Linda. Central africans and cultural transformations in the American diaspora. Cambridge: Cambridge University Press, 2002. Para uma visão diferente, que defende que Luanda foi criada no contexto da expansão do tráfico privado, e não como resposta estatal ao crescimento deste, ver Curto,Jose.Enslaving spirits: the portuguese-brazilian alcohol trade at Luanda and its hinterland, c.1550-1830. Leiden: Brill, 2004.

[24] Birmingham, David. "The date and significance of the imbangala invasion of Angola". Journal of African History, vol. 6, $\mathrm{n}^{\mathrm{2}}$ 2, 1965 ; Vansina, Jan. "More on the invasion of Kongo and Angola by the Jaga and the Lunda". Journal of African History, vol. 7, no 3, 1966; Miller, Joseph. "The imbangala and the chronology of early central african history". Journal of African History, vol. 13, nº 4, 1972; idem, "Requiem for the 'Jaga'". Cahiers d'Etudes Africaines, vol. XIII, $\mathrm{n}^{\mathrm{Q}}$ 1, 1973; Thornton, John. "A resurrection for the Jaga". Cahiers d'Etudes Africaines, vol. XVIII, $\mathrm{n}^{\mathrm{0}}$ 1-2, 1978; Hilton, Anne. "The Jaga reconsidered". Journal of African History, vol. 22, $\mathrm{n}^{2} 2$, 1981; Miller, Joseph, “Thanatopsis". Cahiers d'Etudes Africaines, vol. XVIII, $\mathrm{n}^{\mathrm{Q}}$ 1-2, 1978; Vansina, Jan, How societies are born: governance in West Central Africa before 1600. University of Virginia Press: Charlottesville, 2004.

[25] Ferreira, Roquinaldo “Transforming atlantic slaving: trade, warfare, and territorial control in Angola, 1650-1800". Los Angeles: Tese de Doutorado, UCLA, 2003.

[26] Ibidem.
XIX. Na primeira metade do século XVII, os embarques cresceram em razão direta das operações militares que consolidaram as expectativas comerciais de portugueses e luso-africanos no hinterland da cidade. As vitórias portuguesas contra os exércitos Mbundu resultaram de alianças com guerreiros nômades conhecidos como Imbangalas, cuja origem é até hoje motivo de controvérsia historiográfica ${ }^{24}$. Muito mais do que forças portuguesas ou eventuais apoios militares do Brasil, a aliança com os Imbangalas esteve na raiz do processo que levou à criação dos presídios do hinterland de Luanda - Kambambe, Mbaka, Massangano e Mpungu a Ndongo. Na condição de aliados dos portugueses, os Imbangalas formariam o reino de Kasanje, cujo processo de "mbundização" criou um contraponto que enfraqueceu o poder português de Luanda ${ }^{25}$. O resultado foi a crescente dificuldade para controlar redes internas do tráfico; o que, por sua vez, forçou uma espécie de diversificação das fontes de escravos trazidos para Luanda. Na segunda metade do século XVII, por exemplo, negociantes de Luanda costumavam enviar seus navios para o "resgate" de escravos em Cabinda e Loango. A estratégia tinha como objetivo evitar as numerosas regras protecionistas que favoreciam grandes negociantes de Luanda - incluindo governadores de Angola. Em Cabinda e Loango, o tráfico estava sob influência dos holandeses, que tinham lá se fixado após serem expulsos de Luanda e Benguela em 1648. Mas, ao contrário de franceses e ingleses, que também enviaram navios para essas regiões no final do século XVII, os holandeses costumavam admitir o tráfico português. Em Luanda, os cativos do norte eram conhecidos como Muxicongos, atraindo especial atenção dos negociantes por causa de uma alegada propensão para o suicídio. No final do século XVII, houve mudanças nos embarques a partir de Luanda, devido à crescente autonomia das redes internas do tráfico e às dificuldades para embarcar escravos. Uma nova região - Benguela - foi integrada ao tráfico atlântico. Ao contrário de Luanda, onde burocratas seesmeravam para subtrair ganhos muitas vezes ilegais dos negociantes, Benguela oferecia boas condições para o comércio, embora anteriormente faltasse uma estrutura comercial que impedia um maior desenvolvimento do tráfico, o que só surgiu depois de um ciclo de guerras, que se estendeu por décadas, entre 1670 e 1720 . Os africanos embarcados de Benguela eram inicialmente levados para Luanda, onde os impostos do tráfico eram cobrados dos capitães de navios, e só então eram embarcados para o Brasil - em geral para o Rio de Janeiro. Escravos "benguelas" se tornaram tão comuns em Luanda que várias comunidades quilombolas com cativos que conseguiam fugir do tráfico foram formadas nos arredores da cidade. Em Benguela, os embarques diretos para as Américas — ou seja, Brasil — só começariam na década de $1730 .{ }^{26}$ 
As dimensões - para além do volume - do tráfico e da história africana em termos de ritmos, procedências, interiorização de áreas de resgates e desembarques, personagens e eventos devem ser analisadas considerando margens atlânticas, estruturas e agências. É aí que a "dinâmica da escravidão no Brasil" pode ser conectada.

\section{A INVENÇÃO dO MULATO}

Marquese defende que a invenção dos mulatos teria sido uma experiência de engenharia social que - junto com o alto índice de alforrias - teria dotado o escravismo brasileiro de uma válvula de escape que contribuiu decisivamente para sua longevidade. Aqui, fazendo o contraponto angolano, tomamos como referência o importante estudo de Alencastro. Para este autor, os mulatos angolanos tinham dificuldades para assimilar traços da cultura européia: "em última instância, há mulatos no Brasil e não há mulatos em Angola". Essa argumentação de Alencastro rompe com parte da historiografia africanista. Linda Heywood, por exemplo, avalia que, em Angola, embora o número de mulatos fosse bem menor do que no Brasil ou CaboVerde, a mestiçagem biológica e cultural era significativa.A causa seria a imigração basicamente masculina, assim como os filhos e filhas das relações episódicas ou duradouras entre homens europeus e mulheres angolanas ${ }^{27}$. Tal dinâmica - é bom destacar - é comprovada pelos registros de batismos da paróquia de Nossa Senhora dos Remédios, em Luanda, que indicam que 95 dos 108 homens europeus que batizaram seus filhos entre 1722 e 1736 eram casados com mulheres nascidas naquela cidade. O contraste com o número - apenas 13 - de homens casados com mulheres européias é brutal. Não surpreende, portanto, que os mesmos registros indiquem que $5 \%$ das crianças batizadas naqueles anos tinham ascendência mestiça. ${ }^{28}$

$\mathrm{Na}$ visão de Alencastro, a pouca densidade demográfica e os preconceitos arraigados frustraram a criação de companhias angolanas militares formadas apenas por mulatos, no século XVII. Na verdade, uma análise do recrutamento e das forças militares não só demonstra que os mulatos cumpriram papel importante nas guerras angolanas como também formavam grupo social coeso e distinto. Mulatos trazidos de São Tomélutaram nas guerras que permitiram aos portugueses criar áreas de influência em Angola, que se estendiam de Luanda até regiões interioranas ao longo do rio Kwanza. Para Cadornega - soldado e membro da câmaras municipais de Luanda e Massangano -, "existem muitos mulatos que são grandes soldados, principalmente nas guerras do interior". ${ }^{29}$ Talvez não se referisse apenas aos mulatos trazidos do Brasil. Não sendo parte do exército regular, sua participação estava restrita ao papel de forças auxiliares e irregulares. No século
[27] Heywood,"Portuguese into African", op. cit., p. 94. Para considerações gerais sobre o caráter masculino dos colonizadores portugueses, ver Elbl, Ivana. "Men without wives: sexual arrangements in the early portuguese expansion in West Africa". In: Murray, Jacqueline e Eisenbichler, Konrad (eds.). Desire and discipline: sex and sexuality in the postmodern west. Toronto: University of Toronto Press, 1996, pp. 61-87.

[28] Livro de batismo da Paróquia dos Remédios, 1720-1736. Arquivo do Bispado de Luanda (ABL).

[29] Ver Alencastro, op. cit., pp. 351352 e Cadornega, António de Oliveira. História geral das guerras angolanas. Lisboa: Agência Geral das Colônias, 1940,v.3, pp. 29-30. 
[30] "Relatório do Governador Fernão de Sousa" [sem data mas certamente escrito entre 1625 e 1630 ]. In: Heintze, Beatriz. Fontes para a história de Angola no século XVII. Wiesbaden: Steiner-Verlag, 1985, p. 333 . Ver "Carta de André Vidal de Negreiros em 13 de maio de 1662". Arquivo Histórico Ultramarino (AHU), Angola, cx. 7, doc. 63; "Carta do Governador de Angola em 18 de março de 1682". AHU, Angola, cx. 12, doc. 72; "CCU em 3 de outubro de 1683". AHU, Angola, cód. 554, fls. 42-42v.; "Carta Régia em 24 de março de 1684". AHU, Angola, cód. 545, fl. 3 ov.; e "Carta do Governador de Benguela em 19 de janeiro de 1794". AHU, Angola, cx. 80, doc. 8. Ver também Cadornega, op. cit., v. 1, pp. 346, 408-409; "CCU em 22 de fevereiro de 1689". AHU, Angola, cód. 554, fl. 25;AHU, Angola, cx.12, doc. 7 .

[31] "Papel de Bartolomeu Bulhão em 14 de janeiro de 1655". AHU, Angola, cx. 6, doc. 29.

[32] "Ofício do Governador de Angola em 15 de dezembro de 1784". AHU, Angola, cx. 69, doc. 47; "Várias noções a respeito de Benguela $e$ Angola (1792)". AHU, Angola, cx. 77, doc. 86. Ver também Corrêa, Elias Alexandre da Silva. História de Angola. Lisboa: Editorial Ática, 1937, vol. 1, p.72.

[33] O "censo" de 1773 foi calculado a partir de duas listas de moradores de duas freguesias de Luanda. Ver AHU, Angola, cx. 57, doc. 34; AHU, Angola, cx. 64 , doc. 63. Para Benguela, ver AHU,Angola, cx. 89, doc. 88; Arquivo Histórico Nacional de Angola (AHNA), cód. 442; AHU, Angola, cx. 89, doc. 88; AHNA, cód. 442, fls. 171v.-172.

[34] Biblioteca Municipal de Luanda (BML), cód.16, fls. 86-108.

[35] Ferreira, op. cit.; AHU, Angola, doc. 34; "Ofício do Governador de Angola em 1 de março de 1773". AHU, Angola, cx. 57, doc. 36. Ver também Corrêa, op. cit., vol. 1, p. 71 .

[36] "Relação dos Oficiais do Regimento de Infantaria de Luanda em 22 de maio de 1781". AHU, Angola, cx. 64 , doc. 22.
XVII, devido à necessidade de fortalecer suas tropas, o governador de Angola André Vidal de Negreiros tentou, em vão, convencer Lisboa a permitir inclusão de mulatos nas forças regulares. A posição metropolitana mudou devido ao recrudescimento das guerras contra o reino da Matamba, na década de 1680 . Além de finalmente dar aval régio ao projeto de recrutamento, Lisboa tomou a ousada decisão de ordenar a criação de uma companhia de mulatos. Segundo Alencastro, a idéia teria sido abortada por causa do preconceito das elites de Luanda, porém é mais provável que o já significativo número de mulatos nas companhias regulares tenha tornado a ordem desnecessária. Em 1682, por exemplo, estes eram acusados de se tornarem membros de ordens religiosas para evitar o recrutamento militar. Ao invés de preconceito, Lisboa ordenou que recebessem salários iguais aos dos soldados brancos. ${ }^{30}$

Diante das dificuldades de recrutamento, propostas para libertar escravos mulatos surgiram mais de uma vez, nos séculos XVII eXVIII. Em troca de alforria, serviriam no exército colonial ${ }^{31}$. Em parte, a proposta foi apresentada porque o peso dos mulatos na população escrava angolana era pequeno. Em Luanda, apenas 344 dos 5.700 escravos eram mulatos, em 1781. Em Benguela, o número era ainda menor, já que existiam apenas quinze escravos mulatos numa população de 2.049 escravos $^{32}$. Nos dois casos, o pequeno número de escravos mulatos tinha relação com a prática de alforria dos filhos que os senhores brancos tinham com suas escravas africanas. No século XVIII, mulatos formavam parcela considerável das populações de Luanda e Benguela. Em Luanda, seu número foi estimado em $26 \%$ e $18 \%$ em 1772 e 1781, respectivamente. Em Benguela, manteve-se na ordem de $12 \%$ nos censos de 1798,1799 e 180133 . Curiosamente, parte dos mulatos que viviam nas duas cidades não era nascida em Angola, mas sim em Portugal e Brasil, de onde tinham sido enviados como degredados políticos e religiosos. Entre 1714 e 1719, por exemplo, $40 \%$ dos degredados enviados para Luanda vieram do Brasil, enquanto $60 \%$ eram provenientes de Portugal.A distinção entre degredados portugueses e "brasileiros" é marcante. Enquanto a vasta maioria dos primeiros era de brancos, $90 \%$ dos "brasileiros" eram mulatos 34 . A regra era que degredados fossem quase imediatamente obrigados a "sentar praça" nas forças militares - seja em Luanda, Benguela, ou nos presídios do interior. Não surpreende, portanto, que o número deles fosse tão elevado nas Forças Armadas 35 . É importante destacar que sua participação não era apenas como recrutas. Em 1781, por exemplo, 16 dos 31 oficiais servindo em Luanda tinham nascido na própria cidade, sendo provável que vários fossem mulatos ${ }^{36}$. Além de Luanda, eram também destacados para servir em outras partes de Angola. Em Mpungu a Ndongo, formavam $35 \%$ dos soldados e quase a totalidade dos 
oficiais ${ }^{37}$. Em Benguela, sua participação girou entre 35 e $45 \%$ nas tropas, no final do século XVIII. ${ }^{38}$

Tantos mulatos nas Forças Armadas acabou por gerar insatisfação entre os oficiais brancos. No final do século XVIII, recém-chegados a Luanda, oficiais reinóis amargamente reclamaram das posições de destaque que os mulatos ocupavam no exército colonial. Sua posição parecia refletir o ponto de vista de Lisboa e, curiosamente, a defesa mais ardorosa dos mulatos veio do próprio governador de Angola, António de Mello, que declarou que "seria errado excluir das Forças Armadas indivíduos por causa da cor da pele" 39 . Mello, que já tinha advogado que Angola fosse "colonizada" por mulatos vindos do Brasil, deixou claro suas divergências com o que, imaginava, era uma deliberada política de exclusão não só de mulatos mas também de soldados negros das Forças Armadas $4^{40}$. Para fortalecer seus argumentos, consultou o governador de Pernambuco, Tomaz José de Mello, sendo informado de decisões da Coroa que recomendavam que, em Pernambuco, os critérios de promoção de oficiais não poderiam ser condicionados pela cor da pele. ${ }^{41}$

\section{DALTONISMO SOCIAL}

Argumenta Marquese que, no século XIX, a "maior ameaça ao escravismo brasileiro veio de fora", no caso a "pressão antiescravista inglesa" para acabar com o tráfico nas décadas de 1930 e 1940. Contrariamente, avaliamos que a reconfiguração interna da sociedade escravista não foi levada em conta, principalmente a densidade das áreas urbanas em desenvolvimento, cenários não-existentes nos séculos XVI, XVII e primeira metade do XVIII. Para Marquese ao contrário dos "dirigentes metropolitanos", as elites políticas e intelectuais que formataram o Estado Nacional "instrumentalizaram" - no século XIX - o tema da ideologia escravista brasileira, por meio das alforrias e da cidadania (leia-se direito ao sufrágio) para libertos e filhos de escravos. Reforça sua hipótese com evidências dos debates nas Cortes de Lisboa, quando da independência, em 1822. Conclui então sobre a gestação de um modelo (definição) de "cidadania altamente inclusiva". Estudos de Gladys Sabina e João Reis — entre outros - têm destacado o contrário42. Qual seja, o quanto o debate sobre participação política no período de independência foi profundamente marcado por tensões raciais. Expectativas de libertos e homens de cor livres estavam em pauta; nas ruas, conveses, tabernas, pasquins e "folhas incendiárias" nas décadas de 1820 e 1830 . O tema do "haitianismo" não era só panacéia - metáfora de controle - pânico manipulado sobre uma revolta escrava em gestação. Ao contrário de algo relativo somente à escravidão e aos significados de liberdade envolventes, evocava justa-
[37] "Notícias do Presídio de Pungo Andongo em 1797". Instituto Histórico e Geográfico Brasileiro (IHGB), lata 29, pasta 14, fls. 15-15v.

[38] "Notícias de Benguela em 1797". IHGB, lata 32, pasta 2; AHU, Angola, cx. 89, doc. 88;AHN, Angola, doc. 441 , fl. $88 \mathrm{v}$; AHNA, Angola, cód. 442, fls.171v.-172. Em 1796, por exemplo, três dos sete comandantes selecionados para os postos mais altos naquela cidade eram mulatos. Ver "Ofício do Governador de Benguela em 12 de agosto de 1796". AHNA, Angola, cód. 442, fls. 13 v.-14; "Oficio do Governador de Benguela em 2 de janeiro de 1799". AHNA, Angola, cód. 442 , fls. 68 v. -69 .

[39] "Carta do Governador de Angola em 31 de julho de 180o". AHNA, Angola, cód.152, fls. 1 v.-8.

[40] “'Apontamentos' em 1795". AHU, Angola, cx. 82, doc. 62; "Ofício do Governador de Angola em 23 de agosto de 180o". AHNA, Angola, cód. 6, fls. 148-151 e AHU, Angola, cx. 96, doc. 49; "Ofício do Governador de Angola em 30 de abril de 1798". AHNA, Angola, cód. 5, fls. 92-93.

[41] "Oficio do Governador de Pernambuco em 28 de novembro de 1798". AHNA, Angola, cód. 250, fls. 35 v.-36; "Ofício do Governador de Angola em 24 de dezembro de 1798 ". In: Arquivos de Angola. Luanda, $2^{\text {a }}$ Série, vol. XX, nos 79-82, 1962, pp. 63-65.

[42] Flory, Thomas. "Race and social control independent Brazil". Journal of Latin American Studies, vol. 9, $\mathrm{n}^{\mathrm{Q}} 2$, nov. 1977; Reis, João José. “O jogo duro do Dois de Julho: O 'Partido Negro' na independência da Bahia". In: Reis, João José e Silva, Eduardo. Negociação e conflito: a resistência negra no Brasil escravista. São Paulo, Cia.das Letras, 1989, pp. 79-97; Ribeiro, Gladys Sabina. “'Pés-de-chumbo' e 'garrafeiros': conflitos e tensões nas ruas do Rio de janeiro no Primeiro Reinado (1822-1831)". Revista Brasileira de História, São Paulo, vol. 12, $\mathrm{n}^{\mathrm{O}}$ 23 -24, set. 91/ago. 92, pp. 141-165; e idem, A liberdade em construção. Identidade nacional e conflitos antilusitanos no Primeiro Reinado. Rio de Janeiro: Relume-Dumará, 2002. 
[43] Helg, Aline. "The limits of equality: free people of color and slaves during the first independence of Cartagena, Colômbia, 1810-1815". Slavery \& Abolition, vol. 20, $\mathrm{n}^{\mathrm{Q}}$ 2, ago. 1999 , pp. 21-24, e "Simon Bolívar and the spectre of pardocracia: Jose Padilla in post-independence Cartagena". Journal of Latin América Studies, vol. 35, part 3, ago. 2003, pp. 447-471.
[44] Nova Luz Brazileira, sexta, 11/12/ 1829, pp. 10-12. Ver ainda: Basille, Marcelo.Ezequiel Correa dos Santosum jacobino na Corte imperial. Rio de Janeiro: FGV, 2001. mente o papel que a questão racial poderia ter em termos políticos numa nação emergente. No Brasil, talvez mais do que em qualquer outra sociedade escravista, o medo do Haiti não evocava somente levantes escravos generalizados, mas fundamentalmente anarquia, desordem, caos e ruptura da ordem social pós-colonial, também em termos de ideologias raciais entre a população livre. Há evidências semelhantes para Venezuela em meio à formação do Estado Nacional e o debate sobre fim do tráfico ${ }^{43}$. Quem eram os cidadãos? Origens sociais eétnicas? Afinal, quais os limites dessa cidadania em termos de imagens de raça e nacionalidade? A imprensa teve um papel destacado na propaganda e circulação das idéias, mas o debate era mais amplo e estava nas ruas. No Primeiro Reinado, um dos focos foi o jornal Nova Luz Brazileira, identificado aos liberais exaltados e redigido pelo boticário Ezequiel Correia dos Santos no Rio de Janeiro entre 1829 e 1831. Num tiroteio jornalístico intenso, devemos perscrutar os deslizamentos sociais dos significados desses debates. O Nova Luz Brazileira afirmava: "os pardos são fortes, são talentosos, são verdadeiros amigos da Pátria, são nesta melhor que muitos brancos"; acusando: "se trata na Corte, e nas províncias contra a Constituição, e contra pardos e negros, aos quais se pretende fazer caso venha o absolutismo o que fizeram a eles em São Domingos, os franceses". 44 Não apenas evocava o temor de revoltas escravas, mas o exemplo de uma sociedade sob conflitos raciais e de classe. E mesmo o acesso "inclusivo" ao voto deve ser matizado para a população negra.

Nessa parte, o salto olímpico das interpretações de Marquese é admirável. Abandona os obscuros séculos XVII e XVIII — com cativos rebeldes mas sem consciência e de fazendeiros sem treinamento ideológico adequado - e nos leva rapidamente para o início do século XIX. Espaço privilegiado para a batalha final de escravos obtusos versus senhores e elite política perspicazes. Andamos longe de qualquer análise esfarrapada de luta de classe ou cultura política para além das decisões racionais e eloqüentes vindas dos palácios, varandas e alpendres. No Brasil, uma ideologia escravista para manter a segurança do Estado Nacional numa nova "configuração sistêmica" do século XIX - no "quadro social escravista interno altamente estável" - evitaria tanto "a repetição de Palmares" como "qualquer chance de uma revolução escrava como a de São Domingos". Enfim, um escravismo sem riscos? Como? Através da "blindagem criada", mantendo a segurança por meio da ideologia de alforrias a partir da qual haveria "o comprometimento social dos crioulos e mulatos sobretudo quando livres e libertos - com a instituição da escravidão". Marquese enfatiza a "associação dos negros e mulatos libertos e livres com o sistema escravista: o grande anseio econômico e social desses grupos era exatamente a aquisição de escravos, ou seja, tor- 
nar-se senhor". No Brasil há narrativas sobre senhores classificados como mulatos e pardos, e também evidências - o caso de Minas Gerais e a recente biografia do liberto Dutra, na Corte, são interessantes - de libertos possuidores de escravos, mas estas não podem constituir "prova definitiva" da "equação" de Marquese ${ }^{45}$. Transformações econômicas e mobilidade social podem namorar, até casar, mas também se divorciam. Em outras sociedades escravistas nas Américas parte da população de libertos adquiriu escravos e desenvolveu uma economia de mercado nas franjas da plantation e isso não significava necessariamente uma nova "configuração sistêmica do escravismo". Outras questões podem ser levantadas sobre a ideologia de racialização no século XIX, destacadamente a respeito do controle sobre libertos e a população livre de cor. Períodos de generalizados temores de insurreições - via boatos e denúncias - serviram também para o desencadeamento e o recrudescimento da repressão sobre a população negra livre, especialmente os libertos ${ }^{46}$. Foram assim na Corte, em Recife, Salvador e São Luís. Mesmo as tipologias raciais construídas na imprensa, nos censos e na literatura revelam disputas por símbolos que escondiam tensões e expectativas ${ }^{47}$. As imagens sob a miragem da miscigenação construindo - inequivocamente - harmonia foram narrativas hegemônicas a posteriori. Marquese cita Koster para argumentar como viajantes já percebiam um quadro mais amplo de livres de cor e libertos na sociedade escravista brasileira no século XIX. Mas o próprio Koster - um viajante proprietário de escravos - assinala como os libertos não procuravam se afastar muito dos locais de onde tinham sido alforriados. Por quê? Estavam entrelaçados pela ideologia paternalista da alforria? Ou temiam também a reescravização? Ainda são pouco estudados - o que se começa a fazer no Brasil e em Cuba - os processos de reescravização, além da "suspeição generalizada", em que libertos eram confundidos com escravos nas cidades ${ }^{4}$. E aí entramos no debate sobre o sistema de classificação racial do século XIX. Há evidências de interesses deliberados da elite política do Império pela imigração no Sudeste e não pela população das "províncias do Norte", associada aos exemplos de desordens. A oposição aos recenseamentos por parte da população livre pobre tinha também o significado de rejeitar formas de controle e os temores de reescravização. Foi o caso da revolta camponesa dos Marimbondos em Pernambuco, em 1852, quando camponeses em áreas de expansão econômica temiam a reescravização - que acreditavam ser iniciada pelo recenseamento provincial - numa conjuntura de pressão demográfica pós-cessação do tráfico. 49

Marquese convence mais quando argumenta sobre os padrões de alforrias. Há inúmeros e dispersos estudos para áreas coloniais e pós-
[45] Ver Luna, Francisco Vidale Costa, Iraci del Nero da. "A presença do elemento forro no conjunto de proprietários de escravos". Ciência e Cultura, vol. $32, \mathrm{n}^{\mathrm{e}} 7$, jul. 1980, pp. $836-$ 841; e Frank, Zephir. Dutra's world. Wealth and family in nineteenth-century Rio de Janeiro. México: University of New México Press, 2004.

[46] Cunha, Manuela Carneiro da. Negros estrangeiros; os escravos libertos e sua volta à África. São Paulo: Brasiliense, 1985; e Reis, João José. A rebelião escrava no Brasil. A história do levante dos Malês em 1835. Cia. das Letras, 2003.

[47] Barickman, B. J. "As cores do escravismo: escravistas 'pretos', 'pardos' e 'cabras' no Recôncavo baiano, 1835". População e Família. Centro de Estudos e Demografia Histórica da América Latina. São Paulo, Humanitas/FFLCH/USP, 1988; e Lima, Ivana Stolze.Cores, marcas efalas. Sentidos da mestiçagem no Império do Brasil. Rio de Janeiro:Arquivo Nacional, 2003.

[48] Karasch apresenta algumas referências sobre revogação de alforria no Rio de Janeiro do século XIX. Há pesquisas em andamento de Sidney Chalhoub sobre reescravização e políticas de domínio no Brasil. Ver Chalhoub, Sidney. Machado de Assis, o historiador. São Paulo: Cia. das Letras, 2003.

[49] Palacios, Guilhermo. "A 'Guerra dos Maribondos': Uma revolta camponesa no Brasil escravista (Pernambuco, 1851-1852) Primeira Leitura". História: Questões $\&$ Debates, Curitiba, vol.10, $\mathrm{n}^{\mathrm{0}} \mathrm{s}$ 18-19, jun.-dez.1989, pp. 7-75.

[50] Cano,Jéferson. Escravidão, alforrias e projetos políticos na imprensa de Campinas, 1870-1889. Campinas: Dissertação de mestrado em História, Unicamp, 1993; Damásio, Adauto. Alforrias e ações de liberdade em Campinas na primeira metade do Século XIX. Campinas: Dissertação de mestrado em História, Unicamp, 1995; Florentino, Manolo. "Alforria e etnicidade no Rio de Janeiro oitocentista: notas de pesquisa". Topoi, n. 5, 2002, pp. 2540; Martins, Robson L. M. “'Atos dignos de louvor': imprensa, alforrias e abolição". Afro-Ásia, Salvador, $\mathrm{n}^{\mathrm{Q}} \mathbf{2 7}$, 
2002, pp. 193-222; Moreira, Paulo R. S. Faces da liberdade, máscaras do cativeiro: experiências de liberdade e escravidão, percebidas através das cartas de alforria - Porto Alegre (1858-1888). Porto Alegre: Edipucs, 1996; Nishida, Mieko. "As alforrias e o papel da etnia na escravidão urbana: Salvador, Brasil, 1808-1888". Estudos econômicos, São Paulo, vol. 23, n² 2, 1993, pp. 22765; Oliveira, Maria I. C. de. O liberto: seu mundo e os outros, Salvador, 179o1890.Salvador:Corrupio,1988;idem, "Viver e morrer no meio dos seus. Nações e comunidades africanas na Bahia do século XIX". Revista USP, São Paulo, n. 28, dez. 1995/fev. 1996; Paiva, Eduardo F. Escravos e libertos nas Minas Gerais do século XVIII: estratégias de resistência através dos testamentos. São Paulo: Annablume, 1995; idem, Escravidão e universo cultural na colônia: Minas Gerais, 1716-1789. Belo Horizonte: UFMG, 2001.

[51] Sampaio, Antonio Carlos J. de. "A produção da liberdade: padrões gerais das manumissões no Rio de Janeiro colonial, 1650-1750". In: Florentino, M.G.(Org.). Tráfico, cativeiro e liberdade: Rio de Janeiro, séculos XVII$X I X$. Rio de Janeiro: Civilização Brasileira, 2005, pp. 287-329.

[52] Alencastro, L. F. “Proletários e escravos. Imigrantes portugueses e cativos africanos no Rio de Janeiro, 1850-1872". Novos Estudos, n. 21, 1988, pp.30-56; e Gorender, Jacob.O escravismo colonial. São Paulo: Ática, 1980, pp. 427-450.

[53] Ver:Cruz, Maria Cecília Velasco "Tradições negras na formação de um sindicato: Sociedade de resistência dos trabalhadores em trapiche e café, Rio de janeiro, 1905-1930". Afro-Ásia, Salvador, n² 24, 2000 , pp. 243-229; Farias, Juliana Barreto. Entre identidades e diásporas: Negros Minas no Rio de Janeiro (1870-1930). Rio de Janeiro: Dissertação de mestrado em História Comparada, UFRJ, 2004; Mattos, Wilson Roberto de. Negros contra a ordem. Resistência e práticas negras de territorialização no espaço da exclusão social, Salvador, BA (1850-1888). São Paulo: Tese de doutorado, PUC-SP, 2000 ; Reis, J. J. "De olho no canto: trabalho de rua na Bahia na véspera da Abolição". Afro-Ásia, Salvador, no 24, 2000 , pp.199-242; "A Greve Negra de 1857 na Bahia". Revista USP, São Paulo, $\mathrm{n}^{\mathrm{Q}} 18,1993$. coloniais. São amplamente desenvolvidos na historiografia brasileira, com formulações teóricas e tipologias $5^{5}$. Porém, não podemos somar - generalizando - o impacto de alforrias no Recôncavo e em áreas urbanas da Bahia com os índices para Minas Gerais no século XVIII; regiões cafeeiras de Campinas e aquelas urbanas do século XIX, no Rio de Janeiro e em Porto Alegre. Evidências para alforrias no século XVII ainda são escassas e não podem ser generalizadas, sob alegação de que "ganharam impulso" no "período conturbado da economia açucareira". No Rio de Janeiro elas aparecem ao mesmo tempo da montagem das empresas do açúcar ${ }^{51}$. A interpretação "nacional" (freqüentemente urbana e novecentista) sobre as alforrias deixa de fora quadros sociodemográficos e étnicos fundamentais. Gorender mostra o recrudescimento das alforrias em Minas Gerais com o declínio da mineração. Alencastro fala das mesmas para o Rio de Janeiro do século XIX num momento de retração do mercado de trabalho e uma maior oferta de trabalhadores com a imigração portuguesa ${ }^{52}$. Até podemos falar de "padrões" (mulheres, crioulos e crianças), mas não de "norma básica". Em cidades como Salvador, São Luís, Rio de Janeiro e Porto Alegre, verificam-se lógicas e agências dos próprios escravos (especialmente africanos do setor de serviços) numa cultura de classe e organização étnica do mercado de trabalho para pensar as manumissões e suas séries53. Há matizes para contextos específicos. Sem falar no papel das entidades associativas, pecúlio e alforrias de pia ${ }^{54}$. Uma pergunta em tom de simulação: como eram as manumissões nas áreas cafeeiras do vale do Paraíba (Vassouras, Valença e Paraíba do Sul) no século XIX? Será que não teríamos ali um quadro semelhante de "escravismo de plantation, no qual a produção econômica se concentrava em um único produto e o quadro social era marcado por desbalanço demográfico entre brancos livres e escravos negros, amplo predomínio de africanos nas escravarias, poucas oportunidades para a obtenção de alforria e altas taxas de absenteísmo senhorial", sugerido por Marquese? Não há notícias de índices de alforrias e grandes quilombos nesta região, mas massivo tráfico interprovincial, crioulização, fugas temporárias endêmicas e articulação das mesmas em microcomunidades de roceiros libertos e a economia própria nas senzalas 55 . Avaliamos a necessidade de procurar outras interpretações, comparando - e não generalizando - com áreas atlânticas. No caso, não uma comparação entre Brasil, Cuba, Jamaica e Estados Unidos, mas sim com algumas áreas do Sul algodoeiro americano com o vale do Paraíba cafeeiro; zonas de mineração de Choco, na Colômbia, com Minas Gerais; Recôncavo baiano com as montanhas venezuelanas - por exemplo - , tentando avaliar o fenômeno dos quilombos/maronage, estrutura agrária e demográfica, pressões econômicas externas, políticas de domínio, modos de trabalho, redes familiares e agência de escravos e senhores..$^{6}$ 
Ao procurar uma explicação para o não surgimento de grandes quilombos nos séculos XVIII e XIX, Marquese acaba indiretamente reforçando uma interpretação evolucionista de Genovese sobre a resistência escrava nas Américas, "restauracionista" versus "revolucionária", na passagem do século XVIII, pois vê em demasia diferenças entre quilombos e insurreições. Em Pernambuco no século XVII houve rumores de revoltas em plena época de Palmares. Em Minas há evidências de planos de revoltas nas áreas de mineração e no século XIX abundam quilombos e revoltas, muitas vezes articuladas com setores de libertos. Nos anos de 1820 são várias as evidências de levantes escravos no Grão-Pará, Bahia e Maranhão. Na década de 1830, insurreições escravas se misturaram a movimentos rurais como Cabanada, Balaiada, Farroupilha e Cabanagem. Havia quilombos próximos a todos esses movimentos. No Maranhão e Pará foram numerosos e populosos. Revoltas escravas se espalharam ao longo do século XIX: 1832, em Campinas (SP); 1833, em Carrancas (MG); 1838 , em Vassouras (RJ); 1854, em Taubaté e São Roque (SP); 1857-1859, em Bananal (RJ); 1864, em Serro (MG); 1867, em Viana (MA); 1871, em Itapemirim (ES); 1882, em Resende (RJ); 1883, em Campinas (SP); e 1884-1885, em São Mateus (ES). Rumores, denúncias, planos descobertos, processos e condenações são exemplos. Isso não é pouco, embora só agora tenham surgido estudos monográficos a respeito. Um relatório provincial de Minas Gerais para a década de 1860 assinala inúmeras insurreições escravas ${ }^{57}$. Marquese, como fez Nedell, pode objetar que se tratava apenas de medos pânicos e que não mudaram o jogo de xadrez da sociedade escravista. Enfim, algumas interpretações insistem em considerar que somente senhores e elite política conhecem as peças e as regras do tabuleiro ${ }^{8}$. Podemos argumentar sobre o papel da percepção e conjuntura política e demográfica em torno desses episódios articulando macro e micropolíticas das elites, setores negros, escravos num contexto interno e também internacional, com os debates parlamentares das leis antiescravistas, abolição da escravidão no Caribe, questão Christie, Guerra Civil norte-americana e Guerra do Paraguai. Mais do que movimentos excludentes, levantes escravos e quilombos se articularam a outros movimentos. Temos evidências disso em relação às revoltas baianas, a Campinas (1832), Vassouras (1838), Serro (1864) e São Mateus (1884-1885). Isso sem falar na insurreição quilombola de Viana, no Maranhão, em $1867^{59}$. Ali, como ocorreria na Jamaica e Guianas em fins do século XVIII, os quilombolas - articulados e sabedores das políticas e intenções de fazendeiros e autoridades policiais - invadiram vilas e produziram por escrito um protesto. A idéia de revoltas abolicionistas (ou, como argumenta Craton, protocamponesas para o Caribe) não está muito distante da experiência de alguns levantes no Brasil do século XIX, embora as tentati-
[54] Chalhoub, op. cit.; Moreira, Paulo Roberto S. Os cativos e os homens de bem. Experiências negras no espaço urbano. Porto Alegre:EST, 2003, cap. 2.

[55] Ver os estudos de Maria Helena Machado: Crime e escravidão. Trabalho, luta e resistência nas lavouras paulistas, 1830-1888. São Paulo: Brasiliense, 1987; e O plano e o pânico. Os movimentos sociais na década da Abolição. Rio de Janeiro, UFRJ/Edusp, 1994. Ver ainda Donald Jr., Cleveland. "Slave resistance and abolitionism in Brazil: the campista case, 1879-1888". Luso-Brazilian Review, vol.13, n² 2, 1976, pp.182-193.

[56] Ver as tentativas de tipologias em: Geggus, David. “The enigma of Jamaica in the 1790: New light on the causes of slave rebellions". William and Mary Quarterly, vol. 44, $\mathrm{n}^{\mathrm{0}} 2,1987$, pp. 274-299; idem, "Slave resistance studies and the Saint-Domingue slave revolt: some preliminary considerations". Occasional Papers Series, Latin American and Caribbean Center, Florida International University, 1983; e Patterson, Orlando. "Esclavos y revueltas esclavas: análisis sociohistorico de la primeira guerra cimarrona, 1665-1740". In: Price, Richard (org.). Sociedades cimarronas. Comunidades esclavas rebeldes en las Américas. Madrid:Siglo Ventiuno, 1981, pp. 187-235.

[57] Genovese, op. cit. Para Minas Gerais, ver: Mota, Isadora Moura. $O$ 'vulcão' negro da Chapada: rebelião escrava nos sertões diamantinos. Campinas: Dissertação de mestrado em História Social, Unicamp, 2005.

[58] Needell no artigo citado por Marquese faz uma crítica à perspectiva dos temores e das percepções políticas analisados por: Azevedo, Célia Maria Marinho de. Onda negra, medo branco. Onegro no imaginário das elites - Século XIX. Rio de Janeiro: Paz e Terra, 1987; Chalhoub, S. "Medo branco de almas negras: escravos, libertos e republicanos na cidade do Rio". Revista Brasileira de História, São Paulo, vol. 8, n 16, mar./ago., 1988; Gomes, F. dos S. Histórias de quilombolas, op. cit.; Graden, Dale T. "Uma lei... até de segurança pública: resistência escrava, tensões sociais e o fim do tráfico internacional de escravos para o Brasil (1835-1856)". Estudos Afro-Asiáticos, Rio de Janeiro, vol. 30 , dez.1996,pp.113-150; eSlenes, Robert 
W. “'Malungu, ngoma vem !': África coberta e descoberta no Brasil". Revista USP, São Paulo, n. 12,1991/1992. Ver ainda: Needell, Jeffrey. "The abolition of the Brazilian slave trade in 1850: historiography, slave agency and statesmanship". Journal of Latin American Studies, v. 33, $\mathrm{n}^{\mathrm{Q}} 4$, nov. 2001.

[59] Andrade, Marcus Ferreira.Rebeldia e resistência: as revoltas escravas na província de Minas Gerais 1831-840, Belo Horizonte: Dissertação de mestrado, UFMG, 1996; Araújo, Mundinha.Insurreição de escravosem Viana1867. São Luís: Sioge, 1994; Mota, op. cit.; Pirola, Ricardo. A conspiração escrava de Campinas, 1832: rebelião, etnicidade e família. Campinas: Dissertação de mestrado em História Social, Unicamp, 2005; e Reis, J. J. “Recôncavo rebelde: revoltas escravas nos engenhos baianos". Afro-Ásia, Salvador, $\mathrm{n}^{\mathrm{Q}} 15,1992$, pp. 100-126.

[6o] Ver, por exemplo, Beckles, Hilary e Watson, Karl. "Social protest and labour bargaining : the changing nature of slaves responses to plantation life in eighteenth-century Barbados". Slavery $\mathcal{E}$ Abolition, vol. $8, \mathrm{n}^{\mathrm{Q}} 3$, dez. 1987, pp. 282-289; e Craton, Michael. "Proto-Peasant revolts? The late slave rebellions in the British West Indies, 1816-1832". Past \& Present, vol. 85, nov.1979, pp.99-125.

[61] Funes, Eurípides. "Nasci nas matas, nunca tive senhor". História e memória dos mocambos do Baixo Amazonas. São Paulo: Tese de Doutorado, FFLCH/USP, 1995; e Gomes, F. dos S. História de quilombolas, op. cit.; e idem, $A$ Hidra e os pântanos: mocambos, quilombos e comunidades de fugitivos no Brasil (séculos XVII-XIX). São Paulo: Hucitec/Unesp, 2005.

[62] Ver Carvalho, José Murilo de. Teatro de sombras. A politica imperial. Rio de Janeiro: Iuperj, 1988; Reis, J. J. O levante dos Malês, op. cit.; e Rodrigues, Jaime. O infame comércio. Propostas e experiências no final do tráfico de africanos para o Brasil (1800-1850). Campinas: Ed. da Unicamp/Cecult, 20oo; e também: Fick, Carolyn. The making of Haiti. The Saint Domingue revolution from below. Knoxville: The University of Tennessee Pres, 1990. O debate sobre as proposições de Genovese continuaram em: Paquete, Robert L. "Social history update: slave resistance and social history". Journal of Social History, 1991. vas de tipologia tenham sugerido mais equívocos e generalizações ${ }^{60}$. Também podemos falar de evidências históricas de tentativas de "tratados" ou "rendição" - entre clandestinas e oficiais - entre quilombolas e autoridades provinciais no século XIX, como Maranhão (1873 e 1879-1880), Pará (1876) e Rio de Janeiro (1876).61

Mais complicado ainda é falar de "fracasso" ou "derrota" na revolta dos Malês, em Salvador, em 1835. Esta, com repercussões internacionais, deu régua e compasso para debates parlamentares, memórias e a produção de opinião pública se não antitráfico, ao menos profundamente antiafricana nos anos 1830 a 1840.Aconteceram como as revoltas do Caribe britânico, com uma dimensão atlântica que ainda está à espera de reflexões mais conectadas. Por caminhos diferentes, Reis, Carvalho e Rodrigues têm destacado o impacto da revolta Malê nas mudanças de mentalidade de fazendeiros e da elite política na administração do Estado Nacional. Mesmo a tipologia sobre a revolta de São Domingos e seu impacto em termos de protesto escravo não pode ser tão esquemática como propôs Genovese. Fick já destacou o papel da tradição da maronage nas décadas de 1780 para entender a eclosão das revoltas de $1791 .{ }^{62}$

Ao contrário de uma inflexão de um certo modelo de "resistência escrava", tão-somente explicada por uma engenharia senhorial ou política das elites, letrados e fazendeiros, é possível propor uma explicação para a disseminação - não a nucleação - de pequenos e médios quilombos no Brasil comparativamente a outras partes das Américas. Os modelos da Jamaica e do Suriname não devem ser absolutizados. No caso brasileiro, a difusão de comunidades em áreas de fronteiras econômicas abertas (nada parecido com Jamaica ou Cuba) ea perspectiva de atividades de roceiros que se articulavam com outros setores econômicos, transformando-as quase em invisíveis, aproximam-se mais das experiências dos quilombos colombianos (palenques) e venezuelanos (cumbes) dos séculos XVIII eXIX.

Sem ironias desnecessárias que muitas vezes rondam o debate acadêmico e intelectual - sempre necessário e cada vez mais ausente-, louvamos a idéia de Rafael Marquese, ao propor o debate (um quaseconvite), testando hipóteses e ensaiando argumentos. Dentro do mesmo espírito, não fizemos neste ensaio nada diferente disso. Perspectivas historiográficas, misturadas com pressupostos teóricos, têm a sua validade, assim com expectativas ideológicas e narrativas envolventes. Em termos historiográficos, as possibilidades de análises comparativas - abordagens atlânticas menos anglófonas - sugerem caminhos interpretativos novos. Corremos o risco talvez de procurar "explicações nacionais" para fenômenos e experiências com dinâmicas próprias, embora conectadas em termos internacionais e sujeitas a interpretações dialógicas. Há muito de cotidiano, micropolíticas, 
eventos e não-eventos necessitando de abordagens e interpretações ${ }^{63}$. E os horizontes interpretativos dos impérios podem (en)cobrir em demasia as paisagens analíticas microscópicas, porém atlânticas. Estreitar estas margens, isolar - realinhando - tempos e espaços históricos, assim como refletir sobre projetos, processos, estruturas e agências - também como propôs Marquese - pode aumentar focos, interesses e mobilizar investigações em torno do conhecimento histórico.

FLÁVIO GOMES é professor da Universidade Federal do Rio de Janeiro. ROQUINALDO FERREIRA é professor da University of Virginia (EUA).
[63] Troillot, Michel-Rolph. Silencing the past. Power and the production of history. Boston: Beacon Press, 1995 (especialmente o cap.3: "An unthinkable history", pp. 70-107).

Recebido para publicação em 15 de setembro de 2007 NOVOSESTUDOS

CEBRAP

80 , março 2008

pp. 141-160 